\title{
HUBUNGAN KONDISI TUTUPAN KARANG HIDUP DENGAN KEBERADAAN IKAN FAMILI CHAETODONTIDAE DI PERAIRAN ATOWATU
}

\section{Relationship between Live Coral Condition and Existence of Chaetodontidae in The Atowatu Sea Waters.}

\author{
La Ode Anshari ${ }^{1}$, Baru Sadarun ${ }^{2}$, Rahmadani $^{3}$ \\ ${ }^{1}$ Mahasiswa Jurusan Ilmu Kelautan, \\ Fakultas Perikanan dan Ilmu Kelautan, Universitas Halu Oleo. \\ Jl. H.E.A Mokodompit Kampus Hijau Bumi Tridharma Anduonohu Kendari 93232, Telp/Fax: (0401) 3193782 \\ ${ }^{2}$ Surel: sadarunbaru@gmail.com \\ ${ }^{3}$ Surel: rahmamustafa47@gmail.com
}

\begin{abstract}
Abstrak
Ikan famili Chaetodontidae merupakan salah satu komunitas pada ekosistem terumbu karang yang berperan penting dalam aliran energi dan menjaga kestabilan ekosistem. Sebaran ikan famili Chaetodontidae sangat ditentukan oleh kondisi dan variasi habitat terumbu karang. Penelitian ini bertujuan untuk mengetahui hubungan kondisi tutupan karang hidup dengan keberadaan ikan famili Chaetodontidae di perairan Atowatu. Pengambilan data kondisi terumbu karang digunakan metode transek garis atau Line Intercept Transect (LIT), sedangkan pengambilan data ikan Chaetodontidae digunakan metode bell transek yang dilakukan secara visual sensus (sensus langsung), sepanjang 70 meter dengan luas pengamatan $2 \times 2,5$ meter yang dilakukan 2 kali ulangan yang mewakili zona reef flat dan reef slope pada tiap stasiun. Hasil dari penelitian ini diketahui bahwa ko ndisi terumbu karang di Perairan Atowatu dalam kondisi sedang. Stasiun 3 merupakan stasiun dengan presentase tutupan karang hidup tertinggi sebesar 38,93\% (kategori sedang). Kelimpahan jenis ikan Chaetodontidae tertinggi sebesar $0,06 \mathrm{ind} / \mathrm{m} 2$ terdapat pada stasiun 3. Hubungan antara persentase tutupan karang hidup dengan kelimpahan ikan Chaetodontidae menggunakan analisis regresi linear sebesar 0.9576, artinya adanya hubungan yang kuat antara tutupan karang hidup dengan kelimpahan ikan Chaetodontidae
\end{abstract}

Kata kunci : Chaetodontidae, kelimpahan, keragaman jenis, Perairan Atowatu, tutupan karang,

\begin{abstract}
Chaetodontidae fishes are one community in a coral reef ecosystem that plays an important role in energy flow and maintaining ecosystem stability. The distribution of Chaetodontidae fishes is largely determined by the condition and variation of coral reef habitat. This study aims to determine the relationship of living coral cover conditions to the presence of Chaetodontidae fishes in Atowatu waters. Data retrieval of coral reef conditions is used as the Line Intercept Transect (LIT) method, while data collection of Chaetodontidae fish is used the bell transect method which is carried out in a visual census (direct census), along 70 meters with an observation area of $2 \times 2.5$ meters. Two replications were representing the reef flat and reef slope zones at each station. The results of this study note that the composition of coral reefs in Atowatu waters is in a moderate condition. Station 3 is the station with the highest percentage of live coral cover at $38.93 \%$ (medium category). The highest abundance of Chaetodontidae fish species is 0.06 ind. $/ \mathrm{m} 2$ at station 3 . The relation between live coral cover and the abundance Chaetodontidae fishes is 0.9576 , which means that there is a strong relationship between live coral cover and the abundance of Chaetodontidae fishes.
\end{abstract}

Keywords: Chaetodontidae, abundance, species diversity, Atowatu waters, coral cover.

\section{Pendahuluan}

Terumbu karang merupakan salah satu ekosistem khas perairan tropik, dengan keanekaragaman jenis biota yang tinggi. Biota yang hidup di terumbu karang merupakan suatu komunitas yang terdiri dari berbagai tingkatan tropik, dimana masing-masing komponen dalam komunitas ini saling tergantung satu sama lain, sehingga membentuk suatu ekosistem yang lengkap. Salah satu jenis biota yang hidup di terumbu karang adalah ikan karang, yang umumnya memiliki tingkat keanekaragaman jenis yang tinggi pada ekosistem tersebut (Supriharyono, 2013).

Terumbu karang mempunyai fungsi sebagai tempat memijah, mencari makan, daerah asuhan bagi berbagai biota laut. Selain itu terumbu karang mempunyai fungsi sebagai pelindung pantai dari degradasi dan abrasi (Sadarun dan Rianse, 2012). Salah satu biota laut penghuni terumbu karang yang memiliki nilai ekonomi adalah ikan karang. 
Ikan karang merupakan salah satu komunitas pada ekosistem terumbu karang yang berperan penting dalam aliran energi dan menjaga kestabilan ekosistem. Sebaran ikan karang sangat ditentukan oleh kondisi dan variasi habitat terumbu karang. Penurunan kondisi terumbu karang baik oleh faktor alam maupun antropogenik juga dengan sendirinya akan memengaruhi distribusi dan sebaran ikan karang dalam suatu area terumbu. Komunitas ikan di ekosistem terumbu karang terdapat dalam jumlah yang besar dan terlihat mengisi seluruh daerah di terumbu, sehingga dapat dikatakan bahwa ikan merupakan penyokong berbagai macam hubungan yang ada dalam ekosistem terumbu (Suryanti, 2011).

Ikan Chaetodontidae merupakan salah satu organisme yang berhubungan langsung dengan terumbu karang dan merupakan kelompok ikan indikator pada ekosistem terumbu karang. Rondonuwu (2013) menempatkan ikan Chaetodontidae sebagai jenis indikator kondisi terumbu karang karena merupakan penghuni terumbu karang sejati, sehingga apabila terjadi degradasi terhadap ekosistem terumbu karang, kehadiran ikan ini sangat penting untuk digunakan sebagai petunjuk menilai dan memantau kondisi terumbu karang.

Ikan Chaetodontidae tersebar di perairan tropis dan subtropis, tetapi sebagian besar jenisnya terdapat di perairan tropis, yaitu 90 persen dari 120 spesis (Mujiyanto, 2011). Di perairan indonesia tercatat lebih dari 50 spesies ikan kepe-kepe yang hidup sebagai penghuni karang (Adrim, 2001).

Perairan Atowatu merupakan deretan terumbu karang tepi (fringing reef) yang terletak di sebelah barat Kota Kendari yang memiliki gugusan karang dengan kondisi terumbu karang yang normal serta kelimpahan ikan Chaetodontidae yang beragam. Hal ini terlihat dari survei awal yang telah dilakukan ditiga titik stasiun. Hasil survei awal menunjukan bahwa adanya hubungan antara kondisi terumbu karang dengan ikan Chaetodontidae di perairan Atowatu.

Berdasarkan hal tersebut sehingga perlu dilakukan penelitian hubungan kondisi tutupan karang hidup dengan keberadaan jenis ikan indikator dengan melihat pengaruh kondisi terumbu karang terhadap keberadaan ikan karang kelompok indikator di Perairan Atowatu.
Belum adanya informasi tentang hubungan antara persentase tutupan karang hidup dan hubungannya terhadap keberadaan ikan Chaetodontidae. Tujuan dilakukannya penelitian ini adalah untuk mengetahui hubungan antara kondisi tutupan karang hidup dengan keberadaan ikan Chaetodontidae di Perairan Atowatu.

\section{Bahan dan Metode}

Penelitian ini akan dilaksanakan pada bulan Oktober 2018 di Perairan Atowatu Kabupaten Konawe, Sulawesi Tenggara. Penelitian ini berlangsung selama kurang lebih 2 bulan yang meliputi pengambilan data lapangan, pengolahan data dan sampai pembuatan laporan.

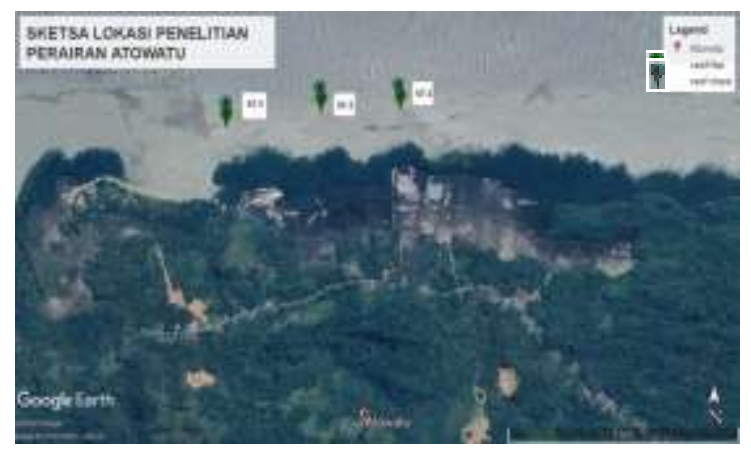

Gambar 1. Lokasi Penelitian Perairan Atowatu (Sumber Geogle Earth 2019)

Pengambilan data hubungan kondisi tutupan karang hidup dengan keberadaan ikan famili chaetodontidae di Perairan Atowatu terdiri dari 2 (dua) aspek yaitu kondisi terumbu karang dan sebaran ikan indikator Chaetodontidae. Data utama juga ditunjang dengan pengukuran parameter kualitas lingkungan perairan (suhu, salinitas, kecepatan arus dan kecerahan).

Pengamatan kondisi terumbu karang pada stasiun penelitian dengan menggunakan peralatan selam SCUBA. Pengambilan data karang menggunakan metode transek garis atau Line Intercept Transect (LIT) (Sadarun, 2012).

Pengamatan ikan indikator pada stasiun penelitian dengan menggunakan metode underwater visual census (UVC) serta dengan bantuan kamera bawah air untuk membantu mendokumentasi beberapa spesies ikan yang belum teridentifikasi (Mujiyanto dan amran, 2014). Pengambilan data dilakukan antara pukul 07.00-17.00. Waktu ini di ambil sesuai 
dengan waktu aktif mencari makan ikan Chaetodontidae yakni pada siang hari (diurnal). Persentase tutupan karang hidup dihitung menurut persamaan English et al, (1994) dengan menggunakan rumus :

$\%$ Cover $=\frac{L i}{L} \times 100 \%$

Keterangan :

$\mathrm{Li}=$ total panjang life form $\mathrm{ke}-\mathrm{I}(\mathrm{cm})$

$\mathrm{L}=$ panjang transek $(\mathrm{cm})$

Penilaian kondisi terumbu karang menurut Keputusan Menteri Negara Lingkungan Hidup Nomor 04 tahun 2001 (Tabel 1).

Tabel 3. Tabel 1. Kriteria penentuan kondisi terumbu karang berdasarkan Keputusan

Menteri Negara Lingkungan Hidup Nomor 04 tahun 2001.

\begin{tabular}{cc}
\hline $\begin{array}{c}\text { Persentase } \\
\text { Penutupan } \\
(\%)\end{array}$ & $\begin{array}{c}\text { Kategori Kondisi } \\
\text { Terumbu Karang }\end{array}$ \\
\hline $0,0-24,9$ & Buruk \\
$25,0-49,9$ & Sedang \\
$50,0-74,9$ & Baik \\
$75,0-100,0$ & Sangat Baik \\
\hline
\end{tabular}

Kelimpahan tiap jenis di stasiun penelitian digambarkan dengan melihat komposisi dan kelimpahan jenis. Kelimpahan jenis didefinisikan sebagai jumlah individu satu jenis per meter kuadran dalam setiap stasiun penelitian. Kelimpahan ikan Chaetodontidae melalui pendataan visual sensus sepanjang transek $70 \mathrm{~m}$, luas $5 \mathrm{~m}\left(70 \times 5=350 \mathrm{~m}^{2}\right)$ dihitung dengan rumus (Riansyah, 2018) :

$N=\frac{\sum n_{i}}{A}$

Keterangan :

$N=$ Kelimpahan ikan (ind/ m2)

$n i=$ Jumlah individu ikan jenis ke-i

$A=$ luas area sensus ikan

Hubungan antara persentase penutupan karang hidup dengan kelimpahan dan jumlah spesies ikan indikator (Chaetodontidae) digunakan Uji Regresi Linear Sederhana dengan menggunakan program excel (Riansyah, 2018). Uji Regresi Linear dilakukan dengan rumus :

$\mathrm{Y}=\mathrm{a}+\mathrm{bx}$

Keterangan :

Y : Subyek dalam variabel dependen yang diprediksi (Kelimpahan ikan karang) $\mathrm{x}$ : Subyek dalam variabel independen yang mempunyai nilai tertentu (Persentase tutupan terumbu karang hidup)

a : Harga $Y$ bila $X=0$ (harga konstanta)

b : Angka arah atau koefisien regresi, yang menunjukkan angka peningkatan ataupun penurunan variabel dependen. Bila $\mathrm{b}(+)$ maka naik dan bila ( - ) maka terjadi penurunan.

\section{Hasil dan Pembahasan}

Perairan desa Atowatu merupakan perairan yang berada pada wilayah laut Kabupaten Konawe, luas wilayah perairan laut Kabupaten Konawe yaitu $11.731 \mathrm{~km}$ atau $10 \%$ dari luas Sulawesi Tenggara dengan ketinggian 0- 500 meter diatas permukaan laut

Parameter fisik kimia perairan berupa suhu, salinitas, kecerahan, kedalaman, kecepatan arus dan intensitas cahaya. Pengukuran parameter fisik kimia peraran dilakukan pada tiap-tiap stasiun penelitian yang selanjutnya disajikan pada Tabel 2 berikut.

Tabel 2. Hasil pengukuran parameter Fisika dan kimia Perairan Atowatu

\begin{tabular}{llccc}
\hline \multirow{2}{*}{ No. } & \multirow{2}{*}{$\begin{array}{c}\text { Parameter } \\
\text { Perairan }\end{array}$} & \multicolumn{3}{c}{ Sasiun } \\
\cline { 3 - 5 } & Fisika & I & II & III \\
\hline & Suhu $\left({ }^{\circ} \mathrm{C}\right)$ & 28 & 29 & 30 \\
2 & Kecerahan (m) & 3.6 & 3.6 & 3.7 \\
3 & Kec. Arus (m/s) & 0.05 & 0.06 & 0.06 \\
\hline \multirow{2}{*}{4} & Kimia & & & \\
4 & Salinitas $(\%)$ & 32 & 32 & 32 \\
\hline
\end{tabular}

Hasil pengukuran parameter Fisika dan kimia Perairan Atowatu pada Tabel 2 diperoleh data lingkungan yang meliputi: suhu, kecerahan, kecepatan arus dan salinitas. Suhu perairan Atowatu cenderung berfluktusi padakisaran normal seiring dengan lamanya penyinaran matahari dan kedalaman perairan, suhu maksimum 30 oC terdapat pada stasiun 3 dan suhu minimum $28{ }^{\circ} \mathrm{C}$ terdapat pada stasiun 1. Bedasar kedalaman menunjukkan nilai tingkat kecerahan tertinggi pada stasiun 3 dengan nilai $3,7 \mathrm{~m}$. Kecepatan arus yang tertinggi terdapat pada stasiun 2 dengan nilai $0,8 \mathrm{~m} / \mathrm{s}$. Distribusi salinitas tergolong nomal terhadap keseluruhan stasiun pengamatan, yaitu $32 \%$. 
Tutupan komponen dasar terumbu karang yang mendominasi dari semua stasiun yaitu Live Coral, Abiotik, Algae, Dead Coral dan Biota lainya (others). Hasil pengamatan terhadap persentase tutupan karang (Gambar 2) diketahui bahwa pada stasiun 1 memiliki persentase tutupan habitat terumbu karang hidup yaitu 25,79\%. Menurut kriteria penentuan kondisi terumbu karang berdasarkan Keputusan Menteri Negara Lingkungan Hidup Nomor 04 tahun 2001 tutupan karang hidup pada stasiun 1 termasuk dalam kategori sedang.

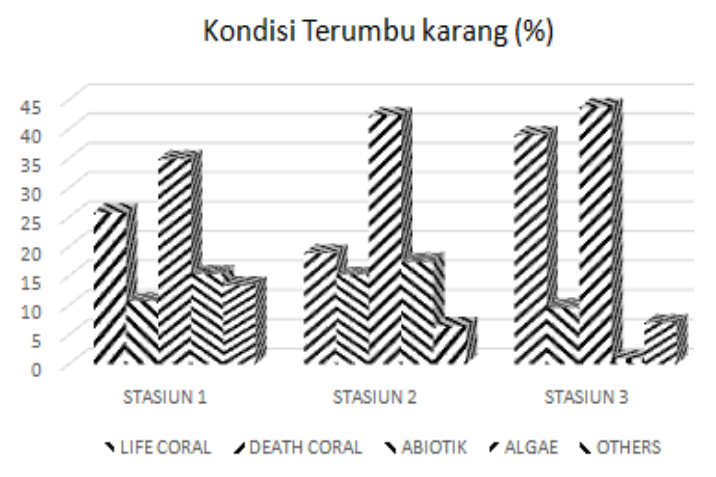

Gambar 2. Presentase Tutupan Karang di lokasi penelitian

Kondisi habitat terumbu karang yang terdapat pada lokasi stasiun 2, dengan persentase tutupan Karang Hidup (Live Coral) 18,86\%. Hal ini dikarenakan pada Stasiun 2 dahulunya merupakan daerah aktivitas destructive fishing khususnya bom, sehingga mempengaruhi persentase Dead coralyangsangat tinggi yakni dengan nilai persentase $15,09 \%$. Titaheluw, $d k k$ (2015) menerangkan bahwa aktivitas pengeboman merupakan factor utama yang mempercepat proses degradasi terumbu karang yang ada di perairan tersebut. Menurut KepmenLH (2001) dengan berdasarkan kisaran tingkat persentase karang hidup, stasiun 2 pada perairan Atowatu tergolong rendah karena memiliki criteria persentase tutupan kurang dari $24,9 \%$.

Kesusakan ekosistem terumbu karang yang terdapat pada staiun 2, dengan persentase Dead coral dengan nilai persentase $15,09 \%$ yang terdiridari pecahan karang mati (Ruble) dan Dead coral with algae (DCA) sehingga menjadi subtrat untuk bebragai macam jenis alga. Hal tersebut dibuktikan dengan persentase Algae yang tertinggi juga terdapat pada stasiun 2, yakni dengan nilai persentase $17,41 \%$ serta komponen persentase tutupan abiotik dengan nilai persentase 42,16\%. Kadi (2005) menerangkan bahwa subtrat batu karang dapat dijumpai pada lokasi yang mempunyai arus deras dan berombak. Makro Alga yang dapat tumbuh dengan cara melekat menggunakan holdfast berbentuk cakram, kebanyakan berada di daerah tubir, menempel pada batu karang matidi daerah rattan terumbu atau pecahan karang bercampur pasir.

Stasiun 3 merupakan daerah dengan persentase tutupan karang hidup tertinggi dari keseluruhan stasiun yakni dengannilai persentase 38,93\% dengan kategori baik. Selain itu persentase Dead coral yang terdaapat pada stasiun ini juga rendah, yakni dengan persentase $9,61 \%$.

Hasil penelitian yang dilakukan diperoleh kelimpahan dan keragaman ikan Chaetodontidae diperairan Atowatu pada 3 stasiun yaitu sebanyak 153 Individu yang terdiri dari 10 jenis ikan Chaetodontidae dan terdiri dari 4 Genus.

Tabel 3. Jenis-Jenis ikan Chaetodonyang ditemukan di perairan Atowatu

\begin{tabular}{llcccc}
\hline Genus & \multicolumn{1}{c}{ Jenis } & ST 1 & ST 2 & ST 3 & Jumlah \\
\hline Chaetodon & Chaetodon klenii & 23 & 7 & 47 & 77 \\
& Chaetodon lunulatus & 0 & 0 & 3 & 3 \\
& Chaetodon punctatofasciatus & 0 & 0 & 4 & 4 \\
& Chaetodon auriga & 2 & 0 & 0 & 2 \\
& Chaetodon ulietensis & 1 & 0 & 0 & 1 \\
& Chaetodon melanotus & 4 & 2 & 1 & 7 \\
& Chaetodon trifacialis & 4 & 4 & 7 & 15 \\
Forcipiger & Chaetodon vagabundus & 9 & 4 & 6 & 19 \\
Heniochus & Forcipiger longirostris & 4 & 0 & 7 & 11 \\
\hline \multicolumn{2}{c}{ Jumlah individu Chaetodon setiap stasiun } & 2 & 2 & 4 & 8 \\
\hline \multicolumn{2}{c}{ Jumlah jenis Chaetodontidae setiap stasiun } & 8 & 19 & 79 & 147 \\
\hline \multicolumn{2}{c}{} & 5 & 5 & 9 & 10 \\
\hline
\end{tabular}




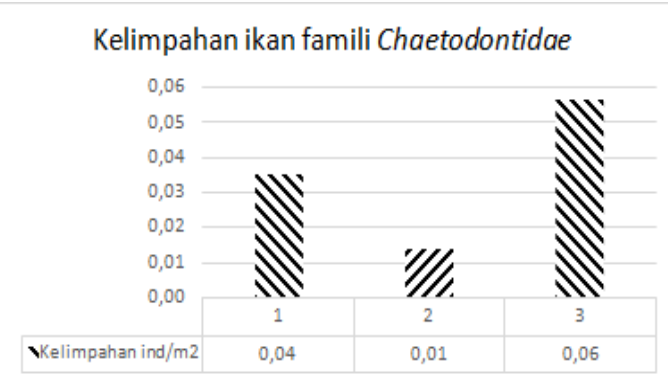

Gambar 3. Histogram kelimpahan Chaetodontidae individu/ $\mathrm{m}^{2}$

Hubungan antara tutupan karang hidup (life coral) dengan kelimpahan ikan karang seperti ikan jenis Chaetodontidae sangatlah berkaitan, dimana ikan jenis ini bergantung pada karang hidup sebagai makanannya dengan memakan polip-polip karang tersebut. Tingginya jumlah individu ikan Chatodontidae pada suatu perairandapat mencerminkan bahwa kondisi suatu terumbu karang berada dalam keadaan baik, yang diidentifikasikan pula dengan tingginya tutupan karang hidup. Meningkatnya jumlah ikan akan berpengaruh terhadap kepadatan dan persaingan dalam memperoleh makanan dan tempat tinggal pada daerah terumbu karang (Suryanti, 2011).

Berdasarkan hasil pengamatan yang disajikan pada Tabel 7 dapat diketahui jenis Chaetodontidae yang sering di temukan pada perairan Atowatubaik pada zona reef flat maupun pada zona reef slope adalah dari jenis C. klenii (77 ekor), C. Vagabundus (19 ekor), C. trifacialis (15 ekor), H. Varius (8 ekor) dan C. melanotus (7 ekor).

Menurut Yusuf dan Ali (2004) mengelompokkan ikan Chaetodontidae jenis $C$. klenii, C. vagabundus, C. trifacialis, $H$. Varius sebagai jenis ikan Chaetodontidaeyang memiliki kebiasaan makan facultative coralivor. Rondonuwu (2014) memperkuat pernyataan tersebut bahawa, salah satu spesies dari Chatodontidae yang sangat umum ditemukan di daerah terumbu karang, bahkan pada daerah-daerah yang telah mengalami kerusakan, dikarenakan spesies ini tidak hanya memangsa polip karang, tetapi juga karang lunak, algae, dan zooplankton (Omnivora).

Kelimpahan jenis atau individu merupakan besarnya populasi dalam hubungannya dengan satuan ruang yang umum dinyatakan sebagai jumlah individu persatuan luas (Mujiyanto, 2014). Dari hasil analisis kelimpahan ikan Chaetodontidae yang terdata secara visual dalam 3 stasiun pengamatan yang mewakili zona reef flat dan reef slope, kelimpahan tertinggi terdapat di stasiun 3 dengan nilai $0,06 \mathrm{ind} / \mathrm{m}^{2}$. Hal ini dikarenakan pada stasiun 3 memiliki kondisi persentase tutupan karang hidup tertinggi dari keseluruhan stasiun yakni dengan nilai persentase 38,93\% dengan kategori baik (Gambar 3). Titaheluw(2015), menyatakan bahwa kelimpahan ikan Chaetodontidae tertinggi ini berkaitan dengan tutupan karang yang masih dalam kategori baik.

Kelimpahan ikan dengan famili Chaetodontidae pada stasiun 1 dengan nilai kelimpahan 0,04 ind $/ \mathrm{m}^{2}$ termasuk dalam kategori sedang. Hal ini juga berkaitan dengan presentase tutupan karang pada stasiun 1 dalam kategori sedang yakni dengan nilai persentase 25,79\%. Pada Stasiun 2 memiliki nilai kelimpahan ikan Chaetodontidae paling rendah yakni dengan nilai kelimpahan $0,01 \mathrm{ind} / \mathrm{m}^{2}$. Hal ini juga berkaitan dengan persentase tutupan karang rendah yakni dengan nilai persentase $18,86 \%$.

Menurut Hutomo dan Adrim (1986), famili Chaetodontidaemerupakan penghuni terumbu karang primer yang khas karena hidupnya selalu berasosiasi dengan terumbu karang baiksebagai habitat maupun tempat mencarimakan.

Hal yang sama juga dikemukakan oleh Suryanti (2011), karena kesukaannya terhadap polip karang sebagai makanan itulah yang menyebabkan penyebarannya selalu ditentukan oleh tutupan karang hidup. Hal tersebut juga mempengaruhi dan menyebabkan kelimpahan ikan Chaetodontidae pada setiap stasiun penelitian di perairan Atowatu berbeda-beda.

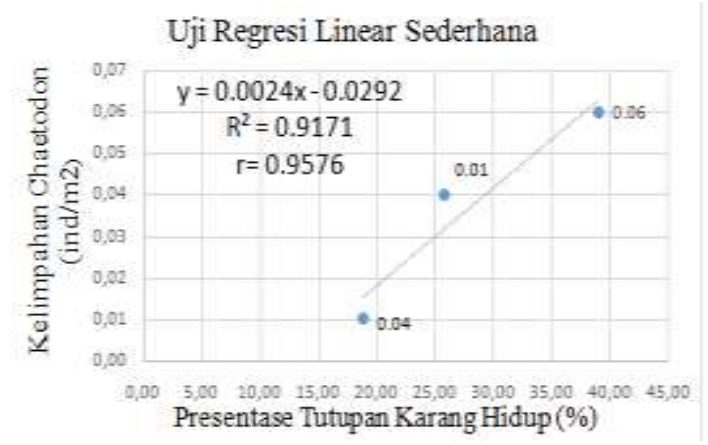

Gambar 4. Keterkaitan ikan Chaetodontidae dengan kondisi tutupan Life Form terumbu karang 
Hasil analisis Uji regresi linear keterkaitan ikan Chaetodontidae dengan kondisi tutupan life form terumbu karang memiliki pola hubungan positif. Pola hubungan tersebut dibuktikan melalui analisis regresi linear sederhana yang menunjukkan persamaan $\mathrm{y}=0.0024 \mathrm{x}-0.0292$ dengan nilai koefisien $\left(\mathrm{R}^{2}\right)$ sebesar 0,9171 dengan determinan sebesar $\mathrm{r}=0.9576$.

Hal ini berarti nilai keterkaitan kelimpahan ikan Chaetodontidae sebesar 0.9576 oleh persentase tutupan life form terumbu karang yang hidup. Riansyah (2014) menerangkan bahwa berdasarkan persamaan yang didapat,terjadi hubungan positif antara persentase tutupan karang terhadap kelimpahan ikan kepe-kepe, artinya apabila persentase tutupan karang (variable $\mathrm{X}$ ) mengalami kenaikan $1 \%$.

Tingginya jumlah individu ikan Chaetodontidae pada suatu perairan dapat mencerminkan bahwa kondisi suatu terumbu karang berada dalam keadaan baik, yang diidentifikasikan pula dengan tingginya tutupan karang hidup.

Berdasarkan penjelasan tersebut, yang menyebabkan keberadaan ikan Chaetodontidae di perairan Atowatu berbeda pada tiap stasiunnya, karena kondisi tutupan life form karang yang berbeda pada setiap stasiun. Tingkat keberadaan ikan Chaetodontidae terutama pada jenis Chaetodon klenni paling mendominansi untuk keseluruhan stasiun di perairan Atowatu. Hal ini sesuai dengan pernyataan dari Hutomo, M, \& Adrim(1986) mengatakan jenis Chaetodon yang masuk dalam kategori omnivora ialah Kepekepe Balon (Chaetodon collare), Kepe-kepe Coklat (Chaetodon kleinii) dan Kepe-kepe Tikar (Chaetodon vagabundus).

\section{Simpulan}

Secara umum kondisi terumbu karang di Perairan Atowatu dalam kondisi sedang dan jenis $C$. klenii merupakan jenis ikan dari family Chaetodontidae yang mendominasi. Stasiun 3 merupakan stasiun dengan presentase tutupan karang hidup tertinggi sebesar 38,93\% (kategori sedang) dengan kelimpahan jenis ikan Chaetodontidae tertinggi sebesar $0,06 \mathrm{ind} / \mathrm{m}^{2}$. Sebaliknya Stasiun 2 merupakan stasiun dengan presentase tutupan karang terendah sebesar $18,86 \%$ (kategori rendah) dengan kelimpahan jenis ikan Chaetodontidae terendah sebesar $0,01 \quad \mathrm{ind} / \mathrm{m}^{2}$.Keterkaitan kelimpahan ikan Chaetodontidae sebesar 0.9576 oleh persentase tutupan life form karang yang hidup.Hal ini disebabkan karena kesukaannya terhadap polip karang sebagai makanan itulah yang menyebabkan penyebarannya selalu ditentukan oleh tutupan karang hidup.

\section{Daftar Pustaka}

Adrim M. 2001. Distribusi Spasial Ikan KepeKepe (Suku:Chaetodontidae) Di Wilayah Pesisir Utara Dari Sulawesi Utara. Bidang Sumberdaya Hayati Laut P2O Lipi Jakarta.

Adrim, M. 2002. Komunitas Ikan Kepe-Kepe (Suku : Chaetodontidae) Di Gugus Pulau-Pulau Derawan Kalimantan Timur. Bidang Sumber Daya Laut. P2O-Lipi Jakarta.

Hutomo, M, \& Adrim., 1986. Distribution of reef fish along trancects in bay of jakarta and kepulauan seribu. Mar Sci, $40: 135$ 156.

Kadi, A. 2005. Makro Algae Di Perairan Pulau Bangka, Belitung dan Karimata. Jurnal Ilmu Kelautan. 10(2):98-105.

Laikun, J., Rondonuwu, A. B., Rembet, U. N. W. J., 2014. Kondisi Ikan Karang Famili Chaetodontidae Di Daerah Perlindungan Laut Desa Bahoi Kecamatan Likupang Barat Kabupaten Minahasa Utara. Jurnal Ilmiah Platax Vol. 2 (3).

Mardasin W. 2011. Studi Keterkaitan Komunitas Ikan Karang Dengan Kondisi Karang Tipe Acropora Di Perairan Sidodadi Dan Pulau Tegal, Teluk Lampung Kab. Pesawaran, Provinsi Lampung. Maspari Jurnal. Vol 3 : 42-50.

Mujiyanto. 2014. Komunitas Ikan Di Terumbu Karang Pulau Semak Daun, Kepulauan Seribu. Jurnal Akuatika. Vol 5 (2) : 112124.

Mujiyanto. 2014. Distribusi Spasial Ikan Family Chaetodontidae Di Perairan Kepulauan Karimunjawa, Jawa Tengah. Jurnal Penelitian Perikanan Indonesia. Vol. 20 (4) : 225-234.

Riansyah, A. 2018. Ikan kepe-kepe (chaetodontidae) sebagai bioindikator kerusakan perairan ekosistem terumbu karang pulau tikus. Vol 35(2) : 103-110.

Rondonuwu, A. B., Rembet, U. N. W. J . 2013. Coral Fishes the Famili Chaetodontidae in Coral Reef Waters of Para Island Sub 
District Tatoareng, Sangihe Kepulauan Regency. Jurnal Ilmiah Platax Vol. 1:4 ,ISSN: 2302-3589.

Rondonuwu, A. B. 2014. Ikan Karang Di Wilayah Terumbu Karang Kecamatan Maba Kabupaten Halmahera Timur Provinsi Maluku Utara. Jurnal Ilmiah Platax. Vol 2 (1), ISSN: 2302-3589.

Sadarun, B., Rianse, U. 2012 Jenis-Jenis karang yang Umum Dijumpai di KKLD Selat Tiworo. Unhalu Press. 50 hal

Suharsono. 2008. Jenis-Jenis Karang Indonesia. Lipi Press. Jakarta Suharti, Sr. 2006. Fish Assemblages On Coral Reefs Of Karimun Jawa Island, Central Jawa, Indonesia. Coastal Marine Science $30(1): 247-251$.

Supriharyono. 2013. Keanekaragaman Jenis Ikan Karang Di Daerah Rataan Dan Tubir Pada Ekosistem Terumbu Karang Di Legon Boyo, Taman Nasional Karimunjawa, Jepara. Diponegoro Journal Of Maquares, Vol. 2 (4) : 81-90.

Suryanti. 2011. Kondisi Terumbu Karang Dengan Indikator Ikan Chaetodontidae Di Pulau Sambangan Kepulauan Karimun Jawa, Jepara, Jawa Tengah. Buletin Oseanografi Marina, Vol 1 : 106119.

Titaheluw, S.S. 2015. Hubungan Antara Ikan Chaetodontidae Dengan Bentuk Pertumbuhan Karang. Jurnal Ilmiah Agribisnis Dan Perikanan (Agrikan UMMU-Ternate). Vol 8 (1).

Yusuf Y, Ali AB. 2004. The Use Of Butterflyfishes (Chaetodontidae) As Bioindicator In Coral Reef Ecosystems. P 175-183 In Phang SM And Brown MT (Eds). Biomonitoring Of Tropical Coastal Ecosystems. Kuala Lumpur: University Of Malaya Maritime Research Center (Ummrec). 